\title{
ANALISIS PENTINGNYA KOMPETENSI SOSIAL GURU TERHADAP PENDIDIKAN KARAKTER PADA MATA PELAJARAN IPS DI SDN 1 MOYOKETEN KECAMATAN BOYOLANGU KABUPATEN TULUNGAGUNG TAHUN AJARAN 2017/2018
}

\author{
Mei Agustina Sintawati ${ }^{1}$, Nourma Oktaviarini ${ }^{2}$ \\ Sekolah Tinggi Keguruan dan Ilmu Pendidikan (STKIP) PGRI Tulungagung \\ mei.agustina96@gmail.com ${ }^{1}$, nourmaoktavia@gmail.com ${ }^{2}$
}

\begin{abstract}
Abstrak
Guru dituntut untuk menguasai berbagai kompetensi dalam menjalankan tugas menjadi pendidik yang baik. Lembaga pendidikan memiliki tanggung jawab untuk menanamkan pendidikan karakter melalui proses pembelajaran. Penelitian ini bertujuan untuk mendeskripsikan dan menganalisis: (1) kompetensi sosial guru di SDN 1 Moyoketen (2) pendidikan karakter di SDN 1 Moyoketen (3) kompetensi sosial guru terhadap pendidikan karakter di SDN 1 Moyoketen. Jenis penelitian ini merupakan deskriptif kualitatif. Metode pengumpulan data menggunakan angket, wawancara, catatan lapangan dan dokumentasi. Hasil penelitian menunjukkan bahwa kompetensi sosial guru kelas III SDN 1 Moyoketen termasuk sangat baik dengan hasil angket yang menunjukkan prosentase sebesar $89.17 \%$. Nilai pendidikan karakter siswa termasuk sangat baik dengan hasil angket yang menunjukkan prosentase sebesar $87.92 \%$. Dapat disimpulkan bahwa kompetensi sosial guru kelas III SDN 1 Moyoketen sangat baik, pendidikan karakter siswa kelas III SDN 1 Moyoketen sangat baik, dan kompetensi sosial guru sangat penting dalam pembentukan nilai pendidikan karakter siswa.
\end{abstract}

Kata Kunci: Guru, Siswa, Kompetensi Sosial, Pendidikan Karakter

\begin{abstract}
Teachers are required to master various competencies in carrying out the task of becoming a good educator. Educational institutions have a responsibility to instill character education through the learning process. This study aims to describe and analyze: (1) teacher's social competence in SDN 1 Moyoketen (2) character education at SDN 1 Moyoketen (3) teacher's social competence on character education at SDN 1 Moyoketen. This type of research is descriptive qualitative. Methods of data collection using questionnaires, interviews, field notes and documentation. The results showed that the social competence of third grade teacher of SDN 1 Moyoketen was very good with the questionnaire which showed the percentage of $89.17 \%$. The value of character education of students is very good with the questionnaire which shows the percentage of $87.92 \%$. It can be concluded that the social competence of third grade teacher of SDN 1 Moyoketen is very good, character education of third grade students of SDN 1 Moyoketen is very good, and teacher's social competence is very important in forming the value of character education of students.
\end{abstract}

Keywords: Teachers, Students, Social Competencies, Character Education 


\section{PENDAHULUAN}

Dalam undang-undang No.14 tahun 2005 tentang Guru dan Dosen disebutkan bahwa Guru adalah pendidik profesional dengan tugas utama mendidik, mengajar, membimbing, mengarahkan, melatih, menilai dan mengevaluasi peserta didik pada pendidikan anak usia dini jalur pendidikan formal, pendidikan dasar, dan pendidikan menengah. Guru wajib memiliki kualifikasi akademik, kompetensi, sertifikat pendidik, sehat jasmani dan rohani, serta memiliki kemampuan untuk mewujudkan tujuan pendidikan nasional. Sementara itu kompetensi yang harus dimiliki guru, meliputi kompetensi pedagogik, kompetensi kepribadian, kompetensi sosial dan kompetensi profesional. Kata kompetensi berasal dari bahasa inggris competency sebagai kata benda

competence yang berarti kecakapan, kompetensi dan kewenangan.

Penelitian terkait kompetensi sosial guru dalam pendidikan karakter diantaranya adalah penelitian oleh Dina Munawaroh (2013) dengan judul "Kompetensi Sosial Guru PAI dan Relevansinya Dengan Pembentukan Karakter Siswa Di SMK Negeri 1 Nglipar Gunungkidul”. Penelitian ini menghasilkan kesimpulan yaitu kompetensi sosial guru PAI di SMK Negeri 1 Nglipar Gunungkidul dicerminkan dalam bentuk kemampuan mengadakan komunikasi dan menjalin hubungan baik dengan semua pihak. Kompetensi sosial guru PAI di SMK Negeri 1 Nglipar Gunungkidul dalam hubungannya dengan siswa diaktualisasaikan melalui kemampuan menjadi fasilitator belajar dengan memberikan kemudahan-kemudahan pada siswa dalam melakukan kegiatan belajarnya. Bahwa kompetensi sosial yang dimiliki oleh guru PAI di SMK Negeri 1 Nglipar Gunungkidul telah memenuhi beberapa aspek pencapaian kompetensi sosial. Hal ini dicerminkan oleh guru PAI di SMK Negeri 1 Nglipar Gunungkidul dalam bentuk keteladanan sikap, kedisiplinan, serta kemampuan berkomunikasi dan bekerjasama dengan orang lain.

Dari uraian di atas dirumuskan beberapa rumusan masalah yaitu (1) Bagaimana analisis kompetensi sosial guru di SDN 1 Moyoketen, (2) Bagaimana analisis pendidikan karakter di SDN 1 Moyoketen, (3) Bagaimana analisis 
kompetensi sosial guru terhadap pendidikan karakter di SDN 1 Moyoketen. Tujuan dalam penelitian ini adalah untuk mendeskripsikan dan menganalisis kompetensi sosial guru di SDN 1 Moyoketen, untuk mendeskripsikan dan menganalisis pendidikan karakter di SDN 1 Moyoketen, untuk mendeskripsikan dan menganalisis kompetensi sosial guru terhadap pendidikan karakter di SDN 1 Moyoketen.

\section{METODE PENELITIAN}

Jenis penelitian yang digunakan dalam penelitian ini adalah penelitian deskriptif kualitatif. Dalam penelitian ini peneliti menggunakan instrumen penelitian antara lain: (1) Observasi, peneliti menggunakan observasi dalam penelitian ini untuk melihat proses pembelajaran IPS di kelas 3. (2) Wawancara, peneliti melakukan wawancara untuk mengetahui secara jelas bagaimana kompetensi sosial guru dan nilai karakter siswa, tentang pelaksanaan pembelajaran, cara dalam mengatasi berbagai karakter siswa yang berbeda-beda. (3) Angket, angket penelitian yang berisi serangkaian pertanyaan atau pernyataan untuk memperoleh informasi yang harus dijawab responden secara bebas sesuai pendapatnya. (4) Catatan lapangan, peneliti menggunakan catatan tertulis dalam penelitian ini yang berisi tentang apa yang didengar, dan apa yang dilihat untuk pengumpulan data. (5) Dokumentasi, peneliti menggunakan dokumentasi ini memfoto hal-hal yang berkaitan dengan penelitian.

Teknik analisis data dalam penelitian ini adalah (1) Reduksi data, data yang diperoleh dari laporan jumlahnya cukup banyak, untuk itu maka perlu dicatat secara teliti dan rinci. (2) Penyajian data penelitian kualitatif bisa dilakukan dalam bentuk uraian singkat, bagan, hubungan antara kategori, dan sejenisnya. (3) Verifikasi atau penyimpulan data, kesimpulan awal yang dikemukakan masih bersifat sementara, dan akan berubah bila ditemukan bukti-bukti yang kuat yang mendukung pada tahap berikutnya. 


\section{HASIL DAN PEMBAHASAN}

Kompetensi sosial guru kelas III SDN 1 Moyoketen dapat dikatakan sangat baik. Hal ini dapat terlihat dari data hasil angket sebagai berikut:

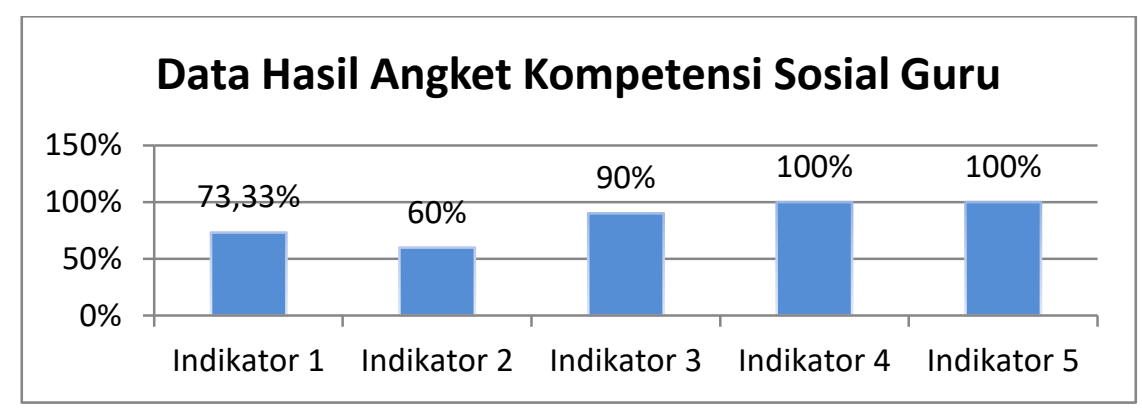

Grafik 1 Prosentase Hasil Angket Guru

Dari data hasil angket di atas dapat diketahui bahwa pada indikator satu mengenai berkomunikasi lisan, tulis, dan/atau isyarat secara santun mendapatkan prosentase sebesar $73.33 \%$ yang termasuk dalam kategori kuat. Guru mampu berkomunikasi lisan, tulis, dan isyarat secara santun dengan siswa. Dari hasil observasi pelaksanaan pembelajaran, guru menggunakan metode ceramah dan tanya jawab pada saat menyampaikan materi. Dari hasil wawancara guru menyatakan bahwa berkomunikasi dan menegur siswa menggunakan kata-kata yang baik. Dari hasil observasi pelaksanaan pembelajaran, ada sebagian siswa yang sibuk berbicara sendiri dengan teman didekatnya, bergurau dan tidak mendengarkan penjelasan dari guru.

Pada indikator dua mengenai menggunakan teknologi komunikasi dan informasi secara fungsional, mendapatkan prosentase sebesar $60 \%$ yang temasuk dalam kategori cukup. Kemampuan guru dalam menggunakan teknologi komunikasi dan informasi dalam kategori cukup. Hal ini terlihat dari guru yang mampu menggunakan HP atau telepon dalam proses bersosialisasi dan pembelajaran. Guru mampu menggunakan berbagai media komunikasi dan informasi untuk kepentingan berkomunikasi dalam hal pendidikan, pembelajaran, dan bermasyarakat.

Pada indikator tiga mengenai bergaul secara efektif dengan peserta didik, sesama pendidik, tenaga kependidikan, pimpinan satuan pendidikan, orang tua 
atau wali peserta didik, mendapatkan prosentase sebesar 90\% yang termasuk dalam kategori sangat kuat. Kemampuan guru dalam berinteraksi dengan peserta didik, teman sejawat, pimpinan, dan wali murid dalam kategori sangat baik. Hal ini terlihat dari guru yang mampu bekerja sama dengan guru lainnya dalam menyiapkan berbagai kegiatan lomba yang diikuti sekolah. Guru berperan aktif ikut membantu menyiapkan kostum tari, atribut lomba, serta mengantar siswa mengikuti lomba.

Guru secara lebih efektif mampu berinteraksi dengan semua kalangan tanpa ada permasalahan. Guru juga menyediakan untuk berkomunikasi dengan wali murid dengan sistem kunjungan ke rumah. Peserta didik yang mengalami kesulitan belajar ada penanganan bimbingan secara individual bersama guru pada pulang sekolah atau jam istirahat. Dari hasil observasi pelaksanaan pembelajaran, guru menghafal semua nama-nama peserta didik dengan baik. Guru menunjukkan kerja sama yang baik dengan staf sekolah yang memerlukan bantuan.

Pada indikator empat mengenai bergaul secara santun dengan masyarakat sekitar dengan mengindahkan norma serta sistem nilai yang berlaku mendapatkan prosentase sebesar $100 \%$ yang termasuk dalam kategori sangat kuat. Prosentase tersebut menunjukkan bahwa kemampuan guru dalam berinteraksi secara santun dengan masyarakat dalam kategori sangat baik. Hal ini bisa dilihat dari interaksi guru dengan mahasiswa, guru bersalaman dengan mahasiswa satu-persatu secara bergantian. Guru membantu mahasiswa yang melaksanaan penelitian di SDN 1 Moyoketen dengan sangat baik. Guru mampu berinteraksi dengan masyarakat sekitar dengan mengindahkan norma dan sistem nilai yang berlaku di masyarakat.

Indikator kelima mengenai menerapkan prinsip persaudaraan sejati dan semangat kebersamaan mendapatkan prosentase sebesar $100 \%$ yang termasuk dalam kategori sangat kuat. Prosentase tersebut menunjukkan bahwa kemampuan guru dalam menerapkan persaudaraan sejati dan semangat kebersamaan dalam kategori sangat baik. Hal ini terlihat dari guru yang mampu memberi teladan yang baik bagi siswa dalam bersikap. Guru ikut serta melaksanakan upacara bendera pada hari senin. Guru memberi contoh yang baik kepada siswa dengan sikap 
disiplin dan cinta tanah air. Dalam upacara bendera guru mencontohkan bagaimana posisi hormat dan posisi siap yang benar.

Pendidikan karakter siswa kelas III SDN 1 Moyoketen dapat dikatakan sangat baik. Hal ini dapat terlihat dari data hasil angket sebagai berikut:

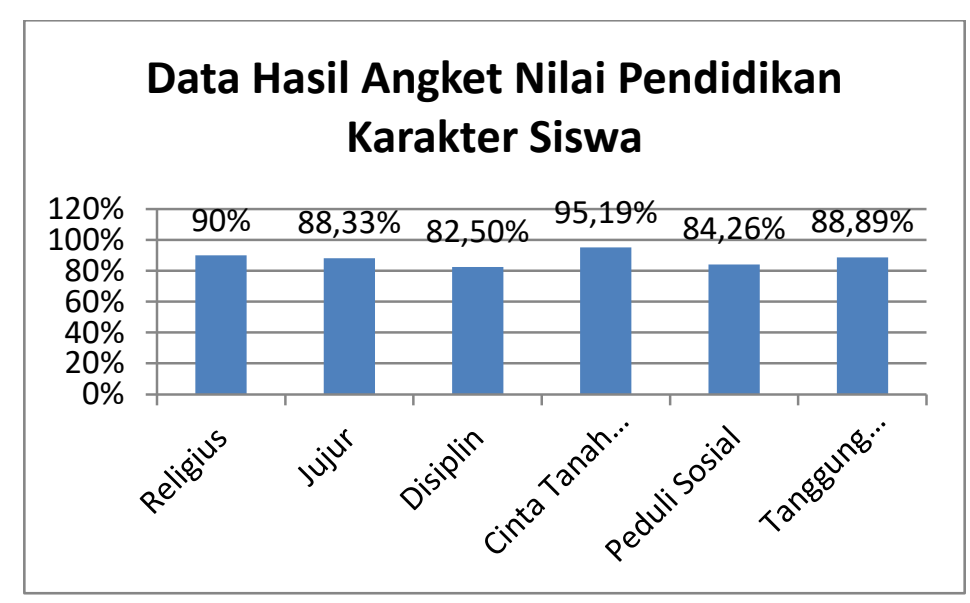

Grafik 2 Prosentase Hasil Angket Siswa dari 6 Indikator

Dari data hasil angket di atas dapat diketahui bahwa tingkat nilai pendidikan karakter siswa termasuk dalam kategori sangat baik. Nilai religius siswa mendapatkan prosentase sebesar 90\% dalam kategori sangat kuat. Siswa sudah mengerjakan ibadah setiap hari dan dari hasil angket mendapatakan prosentase sebesar $77.78 \%$ yang termasuk dalam kategori kuat. Dari hasil wawancara, diketahui bahwa siswa setiap hari melaksanakan ibadah contohnya sholat, mengaji, membaca Al-Qur'an dan membaca jus ama. Siswa melaksanakan ibadah dengan orang tua, teman, dan orang lain. Siswa terbiasa untuk menghargai teman yang berbeda agama, dari hasil angket menunjukkan prosentase sebesar 95\% yang termasuk dalam kategori sangat kuat.

Siswa selalu menerapkan kebiasaan berdo'a sebelum pelajaran dimulai dan sesudah pelajaran berakhir yang ditunjukkan dari hasil angket dengan prosentase sebesar $97.22 \%$ yang termasuk dalam kategori sangat kuat. Dari hasil observasi pelaksanaan pembelajaran, dapat diketahui bahwa guru mengucapkan salam pada saat masuk kelas, semua siswa membalas salam dari guru. Sebelum memulai pelajaran, diawali dengan berdo'a. Membaca do'a dilakukan sebelum pelajaran dimulai dan sesudah pembelajaran berakhir. 
Nilai jujur siswa mendapatkan prosentase sebesar $88.33 \%$ dalam kategori sangat kuat. Siswa mampu berkata jujur dengan orang tua, guru, maupun temantemannya dengan prosentase hasil angket sebesar $85.56 \%$ yang termasuk dalam kategori sangat kuat. Dari hasil observasi pelaksanaan pembelajaran, guru menggunakan metode penugasan dimana guru memberikan soal tambahan kepada siswa yang nilainya di bawah KKM. Siswa terbiasa untuk mengembalikan barang yang dipinjam kepada pemiliknya dengan mendapat prosentase hasil angket sebesar $96.67 \%$ yang termasuk dalam kategori sangat kuat. Dari hasil wawancara, diketahui bahwa siswa terbiasa bersikap jujur dengan semua orang contohnya mengembalikan barang yang dipinjam kepada pemiliknya, membayar jika membeli apapun, dan mengembalikan uang kembalian kepada ibu. Dalam bersikap jujur, siswa mengakui kesalahan yang telah diperbuat dengan prosentase hasil angket sebesar $96.11 \%$ yang termasuk dalam kategori sangat kuat.

Dalam mengerjakan ujian, siswa terbiasa mengerjakan secara mandiri, terlihat dari prosentase hasil angket sebesar 75\% yang termasuk dalam kategori kuat. Dari hasil observasi pelaksanaan pembelajaran, guru memberikan tugas pengayaan untuk semua siswa. Siswa mengerjakan tugas dari guru secara individu tanpa menyontek jawaban temannya.

Nilai disiplin siswa mendapatkan prosentase sebesar $82.5 \%$ dalam kategori sangat kuat. Hal ini terlihat dari siswa yang datang tepat waktu ke sekolah dengan prosentase hasil angket sebesar $84.44 \%$ yang termasuk dalam kategori sangat kuat. Dari hasil observasi pelaksanaan pembelajaran, bisa dilihat bahwa semua siswa datang tepat waktu ke sekolah. Dari hasil wawancara diketahui bahwa siswa bersikap disiplin contohnya dengan datang tepat waktu, mengerjakan tugas tepat waktu, dan memakai seragam lengkap. Dalam berpakaian siswa mememakai atribut lengkap dan seragam rapi dengan prosentase hasil angket sebesar $88.33 \%$ yang termasuk dalam kategori sangat kuat. Dari hasil observasi pelaksanaan pembelajaran, siswa memakai seragam rapi serta memakai atribut lengkap. Dalam hal kedisiplinan, siswa mengerjakan PR saat di rumah dengan memperoleh prosentase hasil angket sebesar $77.22 \%$ yang termasuk dalam kategori kuat. Ketika bel masuk berbunyi siswa akan segera masuk kelas dengan prosentase 
hasil angket sebesar $80 \%$ yang termasuk dalam kategori kuat. Dari hasil observasi pelaksanaan pembelajaran, sebelum masuk kelas, siswa berbaris di depan kelas. Ketua kelas bertugas menyiapkan barisan. Setelah siswa berbaris dengan rapi, siswa dipersilahkan masuk dan satu persatu bersalaman dengan guru.

Nilai cinta tanah air siswa mendapatkan prosentase sebesar $95.19 \%$ dalam kategori sangat kuat. Siswa mampu menghafal Pancasila dengan baik dengan prosentase hasil angket sebesar $97.78 \%$ yang termasuk dalam kategori sangat baik. Dari hasil observasi pelaksanaan pembelajaran, sebelum memulai pelajaran semua siswa membaca Pancasila. Salah satu siswa bertugas menjadi pemimpin dengan maju ke depan kelas. Setiap hari, siswa secara bergantian bertugas menjadi pemimpin. Siswa menghafal Pancasila dan membaca dengan sungguhsungguh.

Siswa sangat baik dalam menghafal lagu Indonesia Raya dengan prosentase hasil angket sebesar $\mathbf{9 7 . 7 8 \%}$ yang termasuk dalam kategori sangat kuat. Dari hasil observasi pelaksanaan pembelajaran, sebelum memulai pelajaran semua siswa menyanyikan lagu Indonesia Raya dengan lantang dan bersungguhsungguh. Siswa bersemangat melaksanakan upacara bendera dengan prosentase hasil angket sebesar 90\% yang termasuk dalam kategori sangat kuat. Upacara bendera dilaksanakan setiap hari Senin jam 7 pagi. Siswa berbaris dengan rapi sesuai kelas masing-masing. Siswa laki-laki membentuk barisan sendiri, dan siswa perempuan membentuk barisan sendiri. Siswa mengikuti upacara bendera dengan tenang dan tertib.

Nilai peduli sosial siswa mendapatkan prosentase sebesar $84.26 \%$ dalam kategori sangat kuat. Hal ini terlihat dari siswa yang memberi sedekah kepada pengemis dengan prosentase hasil angket sebesar $79.44 \%$ yang termasuk dalam kategori kuat. Siswa diketahui melakukan kerja bakti dengan prosentasi hasil angket sebesar $80 \%$ yang termasuk dalam kategori kuat. Dalam hal tolong menolong, siswa meminjami pensil kepada teman dengan prosentase hasil angket sebesar 93.33\% yang termasuk dalam kategori sangat kuat. Dari hasil wawancara, diketahui bahwa siswa menerapkan sikap tolong menolong contohnya 
meminjamkan pensil pada teman, membagi makanan kepada teman, dan menolong orang yang kesusahan.

Nilai tanggung jawab siswa mendapatkan prosentase sebesar $88.89 \%$ dalam kategori sangat kuat. Siswa mampu melaksanakan piket kelas sesuai jadwal dengan prosentase hasil angket sebesar $93.33 \%$ yang termasuk dalam kategori sangat kuat. Siswa bertanggung jawab dalam menjaga serta merawat sarana dan prasarana kelas dengan prosentase hasil angket sebesar $82.78 \%$ yang termasuk dalam kategori sangat kuat. Dari hasil observasi pelaksanaan pembelajaran, siswa menjaga sarana dan prasarana yang ada di kelas seperti meja, kursi, buku dan lain sebagainya. Dinding kelas dan meja terlihat bersih dari coretan.

Siswa bertanggung jawab menjaga kebersihan lingkungan dengan membuang sampah pada tempatnya dengan prosentase hasil angket sebesar 90.56\% yang termasuk dalam kategori sangat kuat. Dari hasil observasi pelaksanaan pembelajaran, di ruang kelas terdapat sebuah tempat sampah. Sehingga siswa tidak pelu jauh-jauh untuk membuang sampah. Siswa membuang sampah pada tempat sampah yang telah disediakan di kelas. Siswa yang piket bertugas membuang sampah yang ada di kelas ke tempat pembuangan.

Kompetensi sosial guru kelas III SDN 1 Moyoketen termasuk dalam kategori sangat baik. Begitu juga dengan pendidikan karakter siswa kelas III SDN 1 Moyoketen termasuk dalam kategori sangat baik. Hal ini dapat dilihat dari hasil angket sebagai berikut:

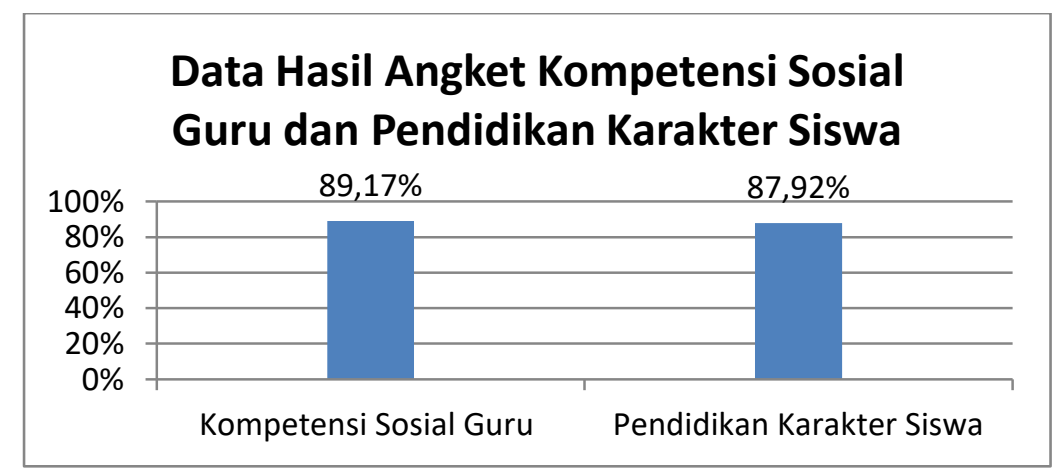

Grafik 3 Hasil angket guru dan siswa

Data di atas menunjukkan bahwa kompetensi sosial guru dan pendidikan karakter siswa sama-sama mendapatkan prosentase yang tinggi. Dapat dikatakan 
bahwa kompetensi sosial guru sangat penting dalam pembentukan nilai pendidikan karakter siswa. Hal ini menandakan peserta didik memiliki rasa hormat terhadap guru sehingga keduanya baik guru maupun peserta didik memiliki interaksi yang baik dan saling menghargai.

\section{KESIMPULAN DAN SARAN}

Penelitian ini menghasilkan kesimpulan yaitu kompetensi sosial guru kelas III SDN 1 Moyoketen dapat dikatakan sangat baik dengan hasil angket yang menunjukkan prosentase sebesar $89.17 \%$. Pendidikan karakter siswa kelas III SDN 1 Moyoketen dapat dikatakan sangat baik dengan hasil angket yang menunjukkan prosentase sebesar $87.92 \%$.

Beberapa saran yang dapat dikemukakan peneliti antara lain bagi siswa, supaya terus menerapkan nilai-nilai pendidikan karakter dalam kehidupan seharihari baik di rumah, di sekolah, maupun di masyarakat. Bagi pendidik, supaya lebih dapat memotivasi siswa untuk bersikap lebih baik lagi dan lebih menekankan kepada siswa pentingnya sikap religius, jujur, disiplin, cinta tanah air, peduli sosial, dan tanggung jawab. Bagi sekolah, supaya meningkatkan dan mempertahankan nilai-nilai pendidikan karakter kepada para siswa dengan cara mendisiplinkan siswa yang melanggar perarturan. Bagi peneliti selanjutnya, peneliti memberikan saran supaya membuat penelitian mengenai pendidikan karakter dengan indikator yang berbeda atau penelitian dengan variabel yang berbeda seperti analisis kompetensi kepribadian guru terhadap pendidikan karakter pada mata pelajaran PKn.

\section{DAFTAR PUSTAKA}

Ashsiddiqi, M. H. (2012). Kompetensi Sosial Guru Dalam Pembelajaran Dan Pengembangannya, XVII(14), 61-67.

Dina Munawaroh. (2013). Kompetensi Sosial Guru Pai Dan Relevansinya Dengan Pembentukan Karakter Siswa Di Smk Negeri 1 Nglipar Gunungkidul.

Francisca, L. (2016). Kompetensi Guru Pada Pendidikan Karakter Berdasarkan Komponen Pembentukan Karakter Di Sebuah Lembaga Pendidikan Non- 
Formal, 3(1), 90-100.

Mulyasa. 2011. Standar Kompetensi Dan Sertifikasi Guru. Bandung: Remaja Rosdakarya.

Retno Anjar Mulatsih. (2017). Analisis Kompetensi Sosial Guru Kelas Sebagai Motivator Untuk Membiasakan Karakter Kedisiplinan Siswa Kelas 5 Di Sdn Taraman 1.

Suardi Kader, S. (2014). Kompetensi Guru Ips Dalam Pembelajaran Berbasis Pedidikan Karakter Di Smp Muhammadiyah Kota Ternate, 1(3), 96-106.

Undang-Undang Republik Indonesia No. 14 Tahun 2005 tentang Guru dan Dosen.

Zubaedi. 2011. Desain Pendidikan Karakter: Konsepsi Dan Aplikasinya Dalam Lembaga Pendidikan. Jakarta : Kencana. 